\title{
Synthesis of Aliskiren
}<smiles>C=CCC(=O)O[C@H](c1ccc(OC)c(O)c1)C(CC=C)C(C)C</smiles>

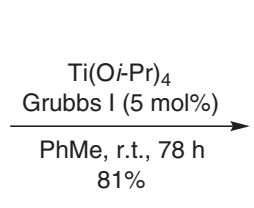<smiles>COCCCOc1cc([C@H]2OC(=O)[C@H](C(C)C)C/C=C\CC2C(C)C)ccc1OC</smiles>

$\mathrm{H}_{2} \mathrm{~N}-\mathrm{SO}_{2} \mathrm{OCH}_{2} \mathrm{CCl}_{3}, \mathrm{MgO}$ $75 \%\left[\mathrm{Rh}\left(\mathrm{CF}_{3} \mathrm{CONH}\right)_{2}\right]_{2}(4 \mathrm{~mol} \%)$ $\mathrm{Phl}(\mathrm{OAc})_{2}, \mathrm{PhMe}, 0^{\circ} \mathrm{C}$ to r.t.<smiles>COCCCOc1cc([C@H]2C(C(C)C)C[C@@H](C3C[C@H](C(C)C)C(=O)O3)N2S(=O)(=O)OCC(Cl)(Cl)Cl)ccc1OC</smiles>

$\frac{\mathrm{TFA}-\mathrm{CH}_{2} \mathrm{Cl}_{2}(1: 5)}{0{ }^{\circ} \mathrm{C} \text { to r.t., } 30 \mathrm{~min}}$<smiles>COCCOc1cc([C@H]2OC(=O)[C@H](C(C)C)CC3C(CC2C(C)C)N3S(=O)(=O)OCC(Cl)(Cl)Cl)ccc1OC</smiles><smiles>CC(C)(CN)C(N)=O</smiles><smiles>COCCCOc1cc([C@H]2C(C(C)C)C[C@H](C(O)CC(C(N)=O)C(C)C)N2S(=O)(=O)OCC(Cl)(Cl)Cl)ccc1OC</smiles>

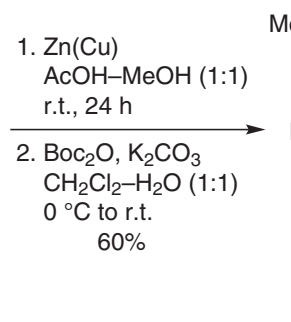<smiles>COCCCOc1cc(C2C(C(C)C)CC(C(O)CC(C(N)=O)C(C)C)N2C(=O)OC(C)(C)C)ccc1OC</smiles>

\begin{tabular}{l|l} 
1. $\mathrm{Na} / \mathrm{NH}_{3}, t-\mathrm{BuOH}-\mathrm{THF},-78{ }^{\circ} \mathrm{C}, 2 \mathrm{~h}$ & $70 \%$ \\
2. $4 \mathrm{M} \mathrm{HCl}$ in dioxane, $0^{\circ} \mathrm{C}, 24 \mathrm{~h}$ &
\end{tabular}<smiles>COCCCOc1cc(CC(C[C@H](N)C(O)CC(C(=O)NCC(C)(C)C(N)=O)C(C)C)C(C)C)ccc1OC</smiles>

Significance: Aliskiren is a novel renin inhibitor that is prescribed for the treatment of hypertension. This short and elegant synthesis features the construction of a nine-membered ring by ringclosing metathesis to give $\mathbf{B}$ followed by an acidcatalyzed rearrangement of the aziridine $\mathbf{C}$ to give pyrrolidine $\mathbf{D}$ in $81 \%$ yield.
Comment: The diene A was an 8:1 mixture of diastereoisomers. The minor (syn) isomer failed to undergo ring-closing metathesis. The rearrangement C $\rightarrow$ D probably involves the initial generation of a benzylic carbocation stabilized by the 4-methoxyphenyl group.

SYNFACTS Contributors: Philip Kocienski

Synfacts 2010, 7, 0735-0735 Published online: 22.06.2010 Dol: 10.1055/s-0029-1220014; Reg-No.: K03110SF 